\title{
TINJAUAN KUALITAS E-BANKING DAN SISTEM PENGENDALIAN INTERN PENERIMAAN KAS (STUDY ON PT BATAM JAYA PROPERTINDO)
}

\section{E-BANKING QUALITY OVERVIEW AND INTERNET CONTROL SYSTEM ACCRUED EXPENSES (STUDI PADA PT BATAM JAYA PROPERTINDO)}

\author{
Rizki Eka Putra ${ }^{1}$ \\ ${ }^{I}$ (Akuntansi, Ekonomi, Universitas Riau Kepulauan, Indonesia) \\ ${ }^{1}$ rizkiekaputra@gmail.com
}

\begin{abstract}
Abstrak
E-Banking adalah salah satu fitur layanan yang dimiliki oleh setiap bank yang digunakan untuk menarik perhatian pelanggan, baik pribadi maupun perusahaan. E-Banking juga memberikan kemudahan akses terhadap informasi akuntansi yang dibuat oleh pelanggan untuk mengetahui secara detail transaksi yang terjadi di bank yang bersangkutan. Setiap perusahaan harus memiliki sistem pengendalian internal dari aset yang paling likuid, yaitu uang tunai. Ini dilakukan untuk menghindari penyalahgunaan uang tunai perusahaan. Penelitian berjudul "Tinjauan Kualitas E-Banking dan Penerimaan Kas Studi Kasus Sistem Pengendalian Intern di PT Batam Jaya Propertindo". Tujuan penelitian ini adalah untuk mengetahui kualitas e-banking yang sesuai dengan sistem pengendalian internal perusahaan dan penerimaan kas yang diterapkan oleh perusahaan telah efektif atau tidak.Metode yang digunakan dalam penelitian ini adalah metode observasi langsung. Dengan wawancara dan literatur. Hasil dari penelitian ini adalah pemilihan layanan bank sesuai dengan kebutuhan dan penerimaan sistem pengendalian internal yang baik dan efektif.
\end{abstract}

Kata Kunci ; Kualitas E-Banking, Sistem Pengendalian Internal Penerimaan Kas

\begin{abstract}
E-Banking is one of the features of the service are owned by each bank being used to attract the attention of customers, both private and corporate. E-Banking also provides ease of access to accounting information made by customers to know in detail the transactions that occurred in the bank concerned. Each company must have internal control system of the most liquid assets, namely cash. This is done in order to avoid any misappropriation of the company's cash. The study titled "Quality Overview E-Banking and Cash Receipts Internal Control System Case Study at PT Batam Jaya Propertindo". The purpose of this study was to determine the quality of e-banking according to the company's internal control system and cash receipts are applied by the company have been effective or not. The method used in this research is the method of direct observation. With interviews and literature. Results from this study is the selection of the bank's services according to the needs and internal control system reception was good and effective.
\end{abstract}

Keywords ; Quality E-Banking, Cash Receipts Internal Control Systems 


\section{PENDAHULUAN \\ Latar Belakang}

Batam merupakan salah satu kota maju yang ada di Kepulauan Riau Indonesia. Letaknya yang strategis menjadikan kota ini menjadi objek para investor untuk menanamkan modal dan membuka suatu perusahaan. Perkembangan yang baik suatu perusahaan tidak hanya dilihat dari seberapa maju dan besar laba yang dicapai, tetapi juga dari penerapan sistem yang digunakan pada perusahaan tersebut. Semakin besar perusahaan tersebut, maka semakin sulit untuk pihak manajemen perusahaan mengendalikan kegiatan usaha. Untuk itu, pihak manajemen memerlukan sistem pengendalian intern yang dapat mengurangi resiko yang diakibatkan oleh kesalahan-kesalahan dan penyelewengan yang mungkin timbul dalam proses penyajian laporan keuangan pada perusahaan tersebut.

Dalam manajemen, pengendalian

intern berperan penting dalam memberikan perlindungan terhadap kelemahan-kelemahan manusia dan mengurangi timbulnya kesalahan-kesalahan dalam penyajian laporan keuangan. Hal tersebut terjadi karena adanya fungsi pemeriksaan (check) dan peninjauan ulang (review) yang melekat pada sistem pengendalian intern. Menurut James A. Hall (2011:6) sistem adalah kelompok dari dua atau lebih komponen atau subsistem yang saling berhubungan yang berfungsi dengan tujuan yang sama. Suatu sistem terdiri dari unsur-unsur yang saling berhubungan erat, bekerjasama untuk mencapai tujuan dan merupakan bagian dari sistem lain yang lebih besar (Mulyadi:2001). Sistem harus mengarah ke satu atau beberapa tujuan yang dapat memberikan ukuran waktu, daya listrik atau informasi maka sistem tersebut harus tetap mengarah ke suatu tujuan. Jika sebuah sistem tidak lagi mengarah ke sebuah tujuan, maka sistem itu harus diganti.

Salah satu pengendalian internal yang harus dilakukan oleh pihak manajemen perusahaan adalah pengendalian internal terhadap penerimaan kas. Kas dilihat dari sifatnya merupakan aset yang paling lancar dan hampir transaksi yang dilakukan oleh perusahaan dengan pihak luar selalu mempengaruhi kas. Kas merupakan komponen penting dalam kelancaran jalannya kegiatan operasional perusahaan. Karena sifatnya yang likuid, maka kas dapat dengan mudah digelapkan sehingga dibutuhkan pengendalian intern terhadap penerimaan kas perusahaan. PT Batam Jaya Propertindo merupakan perusahaan yang bergerak dibidang sewa-menyewa properti atau ruangan perkantoran. Transaksi kas terjadi hampir setiap hari. Adapun hal yang menjadi perhatian suatu perusahaan dalam memilih bank yaitu terletak pada kualitas e-banking pada bank yang dijadikan sebagai tempat penyimpanan uang oleh perusahaan. Untuk menghindari kecurangan dalam setiap transaksi kas, maka diperlukan pengendalian intern yang efektif. Namun, seberapa efektif pengendalian intern dan kualitas e-banking terhadap pencatatan transaksi kas yang dimiliki harus diuji. Berdasarkan uraian pentingnya pengendalian intern yang baik dan berbagai permasalahan yang berhubungan dengan kualitas e-banking, maka penulis akan melakukan penelitian yang berjudul Tinjauan Kualitas E-Banking dan Sistem Pengendalian Intern Penerimaan Kas Pada PT Batam Jaya Propertindo.

\section{Batasan Masalah}

Agar hasil penelitian mendapatkan hasil yang lebih fokus terhadap permasalahan yang ada dan tidak menyimpang dari sasaran penelitian ini maka harus ada pembatasan masalah. Untuk itu, dalam penelitian ini penulis membatasi masalah terhadap kualitas e-banking pada Bank Mandiri dan Virtual Account Bank QnB yang digunakan sebagai tempat penerimaan kas dari pihak eksternal dan ssitem pengendalian intern penerimaan kas yang belum efektif sehingga harus ditinjau dan diteliti kembali.

\section{Rumusan Masalah}

Dari batasan masalah di atas, maka dapat disimpulkan rumusan masalah pada penelitian adalah sebagai berikut :

1. Bagaimana pandangan terhadap kualitas e-banking pada bank yang digunakan oleh PT Batam Jaya Propertindo? 
2. Bagaimana sistem pengendalian intern terhadap penerimaan kas pada PT Batam Jaya Propertindo?

\section{Tujuan Penelitian}

Adapun yang menjadi tujuan penelitian ini adalah sebagai berikut :

1. Untuk mengetahui pandangan terhadap kualitas bank yang digunakan oleh PT Batam Jaya Propertindo.

2. Untuk mengetahui sistem pengendalian intern terhadap penerimaan kas pada PT Batam Jaya Propertindo.

\section{Manfaat Penelitian}

- PT Batam Jaya Propertindo

Hasil penelitian ini diharapkan dapat menjadi bahan masukan bagi perusahaan untuk memilih bank yang tepat dan dijadikan sebagai tempat penyimpanan uang. Selain itu, penelitian ini diharapkan dapat menjadi pertimbangan dalam pembuatan sistem pengendalian intern terhadap penerimaan kas sehingga dapat berjalan secara lebih efektif dan memberikan kemudahan bagi pihak perusahaan dalam melakukan pencatatan atas transaksi keuangan.

- Penulis

Penelitian ini dapat menambah wawasan pengetahuan dan pemahaman melalui pengaplikasian teori yang diperoleh selama masa perkuliahan dan pengalaman selama bekerja pada PT Batam Jaya Propertindo.

- Mahasiswa / Peneliti Lain

Bagi pihak lain, penelitian ini dapat memberikan tambahan pengetahuan dan referensi yang dapat menjadi bahan khususnya untuk mengkaji topik-topik yang berkaitan dengan masalah yang dibahas dalam penulisan skripsi ini.

\section{TINJAUAN PUSTAKA}

\section{Teori Internet Banking}

Pengertian e-banking yang didefinisikan oleh Federal Information Examination Council (FFIEC, 2003) yaitu pengiriman produk dan jasa perbankan, baik produk atau jasa tradisional maupun yang modern secara otomatis dan langsung ke nasabah melalui saluran komunikasi elektronik dan interaktif.

\section{Faktor-faktor yang mempengaruhi Kualitas e-banking \\ Adapun faktor-faktor yang} mempengaruhi kualitas internet banking dalam penelitian Jun (2001) antara lain sebagai berikut

1. Security (keamanan). Menurut Davis dalam jurnal "Internet Banking Adoption Among Young Intellectuals" (Amin, Hasanudin, 2007) security adalah perlindungan informasi atau sistem dari pengacau atau keluarnya aliran informasi. Security ini terdiri dari privacy (privasi) dan information transaction safety (kerahasiaan informasi transaksi).

2. Ease of use (kemudahan penggunaan). Menurut Davis dalam jurnal "Internet Banking Adoption Among Young Intellectuals" (Amin, Hasanudin, 2007) ease of use adalah perasaan seseorang yang percaya bahwa menggunakan sistem tertentu adalah hal yang tidak memerlukan usaha. Faktor ini terdiri dari :

- Compatibility (kesesuaian).

- User Friendly (situs web mudah digunakan oleh user).

- Easy Login (kemudahan untuk login).

- $\quad$ Speed of Response (kecepatan merespon nasabah).

- Accebility of the website (kemudahan mengakses situs). 
- Functions that customer need (fungsi lain yang dibutuhkan nasabah).

- Easy Navigation (menu navigasi yang mudah).

3. Contents (isi) merupakan kelengkapan fitur dan informasi kepada nasabah melalui situs yang terdiri dari :

- Information of products and service online (informasi tentang produk dan jasa).

- other information that customer need (informasi mengenai produk dan jasa lainnya).

4. Aesthetics (keindahan) merupakan tampilan situs yang menarik yang terdiri dari attractiveness of the website (tampilan situs yang menarik).

5. Accuracy (keakuratan) adalah ketepatan dalam isi maupun tampilan situs web serta ketepatan dalam bertransaksi. Hal ini terdiri dari :

- Accurate online transactions (keakuratan dalam bertransaksi)

- Accurate in interface (keakuratan pada saat menghubungkan).

- Accurate in contents (keakuratan pada isi situs).

6. Timelines (ketepatan waktu) merupakan kemampuan menyajikan informasi terbaru kepada nasabah yang terdiri dari up to date information (informasi terkini).

\section{Teori Sistem Pengendalian Intern}

Menurut James A. Hall (2011:9) sistem adalah serangkaian prosedur formal dimana data dikumpulkan, diproses menjadi informasi dan didistribusikan kepada para pengguna. Menurut George H. Bodnar dan William S. Hopwood (2006:129) pengendalian internal merupakan satu proses yang dipengaruhi oleh dewan direksi perusahaan, manajemen dan personel lain yang dirancang untuk memberikan jaminan yang masuk akal terkait dengan tercapainya tujuan reabilitas pelaporan keuangan, efektivitas dan efisiensi operasi dan kesesuaian dengan pera- turan dan regulasi yang berlaku. Proses pengendalian internal suatu organisasi terdiri dari lima elemen yaitu lingkungan pengendalian, penaksiran resiko, aktivitas pengendalian, informasi dan komunikasi, serta pengawasan.

Menurut James A. Hall (2011:181) sistem pengendalian internal terdiri atas berbagai kebijakan, praktik dan prosedur yang diterapkan oleh perusahaan untuk mencapai empat tujuan umumnya yaitu :

1. Menjaga aktiva perusahaan.

2. Memastikan akurasi dan keandalan catatan serta informasi akuntansi.

3. Mendorong efisiensi dalam operasional perusahaan.

4. Mengukur kesesuaian dengan kebijakan serta prosedur yang ditetapkan oleh pihak manajemen.

\section{Teori Kas}

Menurut Harahap (2011) kas adalah uang dan surat berharga lainnya yang dapat diuangkan setiap saat serta surat berharga lainnya yang sangat lancar yang memiliki syarat yaitu setiap saat dapat ditukar dengan kas, tanggal jatuh temponya sangat dekat, dan kecil resiko perubahan nilai yang disebabkan perubahan tingkat harga.

\section{Unsur-unsur pengendalian intern}

Menurut Mulyadi (2001:164) unsurunsur pokok sistem pengendalian intern antara lain sebagai berikut :

1. Struktur organisasi yang menisahka tanggungjawab fungsional secara tegas. Struktur organisasi merupakan kerangka pembagian tanggung jawab fungsional kepada unit - unit organisasi yang dibentuk untuk melaksanakan kegiatan - kegiatan pokok perusahaan. 
2. System wewenang dan prosedur pencatatan yang memberikan perlindungan yang cukup terhadap kekayaan, utang, pendapatan dan biaya. Dalam organisasi setiap transaksi hanya terjadi atas dasar otorisasi atas pejabat yang memiliki wewenang untuk menyetujui terjadi transaksi tersebut. Oleh karena itu, dalam organisasi harus dibuat system yang mengatur pembagian wewenang untuk otorisasi atas terlaksananya setiap transaksi.

3. Praktek yang sehat dalam melaksanakan tugas dan fungsi setiap unit organisasi. Pembagian tanggung jawab fungsional dan system wewenang serta prosedur pencatatan yang telah ditetapkan tidak akan terlaksana dengan baik jika tidak diciptakan cara cara untuk menjamin praktik yang sehat dalam pelaksanaan.

4. Karyawan yang mutunya sesuai dengan tanggungjawabnya. Bagaimana baiknya struktur organisasi, system otorisasi dan prosedur pencatatan serta berbagai cara yang diciptakan untuk mendorong praktik yang sehat, semua sangat tergantung pada manusia yang melaksanakannya.

Diantara unsur pengendalian internal di atas, unsur mutu karyawan merupakan unsur system pengendalian intern yang paling penting. Jika perusahaan memiliki kar- yawan yang kompoten dan jujur, unsur pengendalian yang lain dapat dikurangi sampai batas minimum dan perusahaan tetap mampu menghasilkan pertannggungjawabkan keuangan yang dapat diandalkan.

\section{Penelitian Terdahulu}

Sakharosa Citra Dewi Fortuna (2013) dengan judul Pengaruh Faktor Individu,Organisasi, dan system Terhadap Penerimaan E-Banking. Tujuan penelitian ini adalah untuk mengetahui faktor - factor apa saja yang mempengaruhi kualitas penerimaan e-banking dikalangan masyarakat. Penelitian ini menggunakan jenis penelitian kuantitatif yang menyimpulkan bahwa penerimaan e-banking disebabkan oleh kuallitas system dan juga sikap individu.

Yulia (2006) dengan judul Analisis Pengendalian Intern Kas dapa PT. Bank Negara Indonesia Cabang Pembatu Binjai. Tujuan penelitian iniadalah untuk mengetahui apakah pengendalian intern kas pada perusahaan tersebut sudah berjalan efektif atau belum. Dengan menggunakan metode penelitian deskriptif, diketahui hasil penelitian bahwa system pengendalian intern penerimaan kas pada Bank Tabungan Negara Indonesia Cabang Pembantu Binjai telah efektif. Hal ini dilihat dari system pengendalian intern pada perusahaan tersebut memenuhi unsur - unsur yang ada pada system pengendalian intern penerimaan kas.

Berdasarkan dua penelitian terdahulu di atas, dapat disimpulkan bahawa pemilihan layanan e-banking disebabkan oleh sikap masyarakat atau perusahaan dalam memberikan keputusan yang sesuai dengan kualitas system pada e-banking yang ada pada 
bank yang digunakan sebagai tempat untuk menyimpan uang. Selain itu keefektifan pengendalian intern penerimaan kas didasarkan pada unsur - unsur pengendalian intern yang merupakan pondasi untuk menghindari penyelewengan terhadap aktiva yang paling likuid dan sangat rentan untuk terjadi kesalahan pada pencatatan transaksi kas.

\section{Kerangka Konseptual}

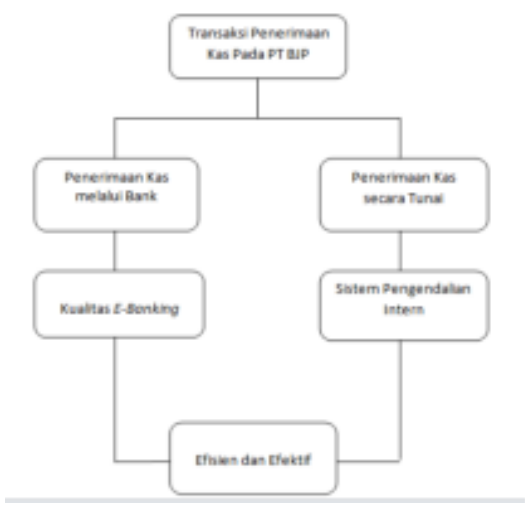

\section{METODOLOGI PENELITIAN}

\section{Jenis Penelitian dan Data}

Jenis penelitian yang digunakan adalah penelitian Kualitatif. Menurut Sugiyono (2010) penelitian kualitatif adalah penelitian yang digunakan untuk meneliti pada kondisi objek alamiah dimana peneliti merupakan instrument kunci. Adapun jenis data yang digunakan dalam penelitian ini yaitu : Data primer adalah data yang dikumpulkan secara langsung oleh objek peneliti dalam melakukan penelitian. Datanya berupa hasil wawancara, rekening koran dari Bank Mandiri dan Bank QnB, dan sebagainya. Data sekunder adalah data yang dikumpulkan dari studi-studi sebelumnya dan bersifat tidak langsung seperti dokumentasi, struktur organisasi perusahaan, dan sebagainya.

\section{Metode Pengumpulan Data}

1. Metode Wawancara

Dalam penelitian ini, akan dilakukan wawancara dengan narasumber yang dapat memberikan informasi mengenai data-data yang dibutuhkan oleh peneliti.

2. Metode Observasi

Metode observasi adalah metode yang mengandalkan kemampuan seseorang untuk menggunakan pengamatannya melalui hasil kerja pancaindra mata serta pancaindra lainnya.

3. Metode Dokumenter

Suatu metode pengumpulan data dalam metode penelitian untuk menelusuri data historis. Dokumenter juga informasi yang disimpan atau didokumentasikan sebagai bahan dokumenter.

4. Metode Penelusuran Data Online Penelusuran yang dilakukan dengan tata cara dan melalui media online, seperti internet, media jaringan lainnya yang menyediakan fasilitas online sehingga memungkinkan peneliti memanfaatkan data informasi berupainformasi teori yang dapat dipertanggungjawabkan.

\section{Uji Keabsahan Data}

Di dalam penelitian kualitatif, peneliti harus melakukan uji keabsahan data yang digunakan sebagai alat untuk membangun teknik pemeriksaan data demi menghasilkan dan menjamin keakuratan data penelitian. Adapun uji keabsahan yang dilakukan menurut Firdaus Hamta,SE,M.Si (2015:122) antara lain sebagai berikut :

1. Perpanjangan keikutsertaan Kehadiran peneliti membantu dalam memahami semua data yang dihimpun dalam penelitian.

2. Ketekunan Pengamatan Untuk keabsahan yang tinggi, maka peneliti penting untuk meningkatkan pengamatan dengan mengandalkan semua panca indra seperti pendengaran, perasaan dan insting peneliti. 
3. Triangulasi dengan Metode

Dilakukan dengan melakukan pengecekan metode pengumpulan data, apakah informasi didapat dengan metode wawancara sama dengan metode observasi, atau apakan hasil observasi sesuai dengan informasi yang diberikan ketika diwawancara.

4. Uraian Rinci

Teknik ini merupakan upaya untuk memberikan penjelasan kepada pembaca dengan menjelaskan hasil penelitian dengan penjelasan yang serinci-rincinya.

\section{Teknik Analisis Data}

Adapun teknik analisis data dalam penelitian ini adalah sebagai berikut :

1. Tahapan awal dengan mengumpulkan persiapan untuk wawancara terhadap informan- informan yaitu koordinator accounting, kepala bagian accounting dan manajer keuangan.

2. Melakukan wawancara dan mengumpulkan data-data penelitian.

3. Melakukan pengamatan terhadap hasil wawancara.

4. Melakukan penelusuran online apabila data yang didapat dari wawancara kurang.

5. Melakukan pengamatan kembali terhadap hasil penelusuran online.

6. Menguraikan secara rinci hasil penelitian.

7. Menyimpulkan hasil penelitian.

\section{HASIL PENELITIAN DAN PEMBAHA-}

\section{SAN}

\section{Bank Yang Digunakan Oleh PT Batam Jaya Propertindo}

PT Batam Jaya Propertindo merupakan perusahaan jasa yang menyewakan properti di gedung Graha Pena Batam. Perusahaan ini merupakan anak perusahaan dari Riau Pos Group dan satu group dengan Batam Pos. setiap perusahaan yang berdiri pasti memiliki akun bank yang digunakan sebagai tempat penyimpanan uang. Karena menyimpan uang di bank lebih aman dan dapat keuntungan dari fitur-fitur yang disediakan oleh bank. PT Batam Jaya Propertindo awalnya hanya memiliki dua rekening bank, yaitu Bank Mandiri (rupiah dan dollar) dan Bank BRI. Perusahaan ini membuat dua rekening bank dikarenakan untuk memberikan kemudahan kepada penyewa dalam melakukan pembayaran.

\section{Alasan Perusahaan Dalam Menggunakan Dua Bank}

Seperti yang sudah dijelaskan di atas, PT Batam Jaya Propertindo menggunakan dua bank karena untuk memperlancar dan memberikan kemudahan kepada penyewa dalam melakukan pembayaran. Selain itu, perusahaan juga menggunakan salah satu bank untuk tempat payroll pada setiap gajian karyawan.

Awalnya perusahaan memilih Bank Mandiri sebagai tempat payroll. Akan tetapi buruknya pelayanan dari Bank tersebut membuat perusahaan mengalihkan payroll ke Bank BRI. Selain itu, sikap staff bank tersebut yang tidak memberikan pelayanan yang memuaskan membuat perusahaan mengambil keputusan untuk memindahkan sistem payroll. Padahal, PT Batam Jaya Propertindo merupakan nasabah prioritas pada bank tersebut.

Akan tetapi, setelah kurang lebih dua tahun menggunakan jasa payroll pada Bank BRI, akhirnya perusahaan memutuskan untuk kembali menggunakan jasa payroll pada Bank Mandiri. Hal ini dikarenakan adanya hubungan kerjasama antara perusahaan dengan Bank Mandiri. Bank Mandiri menyewa tempat untuk mesin ATM (Automatic Teller Machine) yang terletak pada halaman depan gedung Graha Pena Batam. Namun, pada hakikatnya uang yang tersimpan dikedua bank tersebut digunakan untuk membayar beban operasional perusahaan. 


\section{Alasan Perusahaan Menggunakan Virtual Account Bank QnB Indonesia}

Penggunaan dua rekening bank ternyata tidak cukup bagi PT Batam Jaya Propertindo. Hal ini dikarenakan perusahaan sering mendapatkan kesulitan untuk mendeteksi sumber pembayaran yang dilakukan oleh penyewa. Sehingga, hal tersebut dapat menjadi penghambat bagi staff keuangan untuk melakukan pencatatan terhadap penerimaan kas pada bank.

Adanya kesulitan tersebut tentu akan mempengaruhi laporan keuangan pada setiap akhir bulannya. Berikut adalah contoh pembayaran yang tidak diketahui penyetornya dapat dilihat pada gambar 4.2.

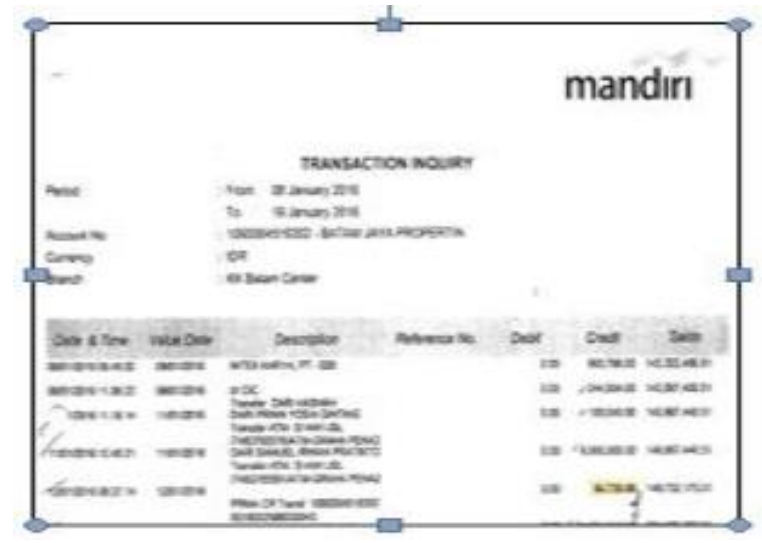

Gambar 4.2

Dari rekening koran di atas, dapat dilihat bahwa ada penerimaan kas pada Bank Mandiri pada tanggal 12 Januari 2016 sebesar Rp 64.735,-. Apabila sampai dengan akhir bulan tidak ada konfirmasi dari pihak penyewa bahwa telah melakukan pembayaran, maka staff keuangan harus mencatat penerimaan tersebut dengan mendebit akun Bank Mandiri dan mengkredit akun hutang lain-lain. Dengan demikian, hal ini tentu tidak akan mempengaruhi posisi saldo piutang usaha meskipun telah diterima pembayaran dari penyewa.

Akan tetapi, apabila ada dari pihak penyewa yang memberikan konfirmasi atas pembayaran yang telah dilakukan, maka staff keuangan akan melakukan pencatatan dengan mendebit akun hutang lain-lain dan mengkredit akun piutang usaha.

Dari kedua transaksi diatas dapat disimpulkan bahwa terdapat ketidakefektifan terhadap pencatatan penerimaan kas pada Bank Mandiri. Karena, hal ini menyebabkan adanya dua kali pencatatan yang dilakuakan oleh staff keuangan . untuk mengatasi permasalahan ini, maka pihak perusahaan memutuskan untuk menggunakan virtual account. Pada saat tersebut, Bank QnB Indonesia yang menawarkan produk atau fitur layanan bank virtual account. Sehingga, perusahaan menggunakan virtual account pada bank tersebut dengan pertimbangan yang baik yang dilakukan oleh pihak manajemen perusahaan.

\section{Manfaat Pencatatan dengan Menggunakan Virtual Account}

Virtual Account adalah nomor indentifikasi pelanggan perusahaan yang dibuka oleh bank atas permintaan perusahaan untuk selanjutnya diberikan oleh perusahaan kepada pelanggannya sebagai nomor rekening tujuan penerimaan. Dengan menggunakan virtual account, maka staff keuangan dapat mendeteksi atau mengetahui penyewa yang telah melakukan pembayaran. Sehingga dengan demikian, staff keuangan dapat langsung melakukan pencatatan atas penerimaan kas pada bank tanpa harus menunggu konfirmasi dari penyewa.

Dengan adanya virtual account akan memudahkan dalam pencatatan terhadap penerimaan kas. Sehingga tidak ada lagi pencatatan yang dilakukan dua kali karena adanya penerimaan kas yang tidak diketahui penyetornya. Uang yang ada di virtual account hanya akan sehari berada di dalam rekening penampungan dan selanjutnya akan langsung otomatis dipindahkan ke rekening induk. Namun, untuk rincian 
pembayaran dari penyewa masih tetap bisa dilihat. Hanya saja uangnya yang tidak ada lagi di dalam rekening tersebut.

Kelebihan dan Kekurangan Bank Mandiri dan Bank QnB Indonesia Berdasarkan Pandangan Perusahaan

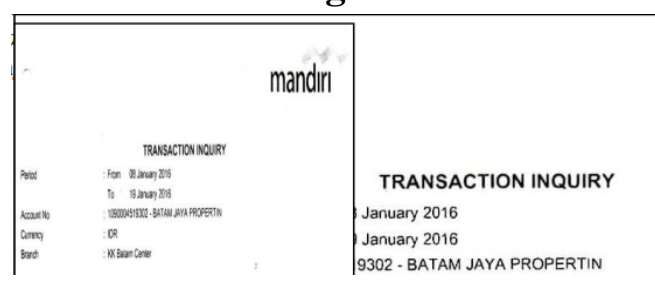

Bank Mandiri

Kelebihan Bank Mandiri antara lain sebagai berikut :

- Terdapat banyak kantor cabang

- ATM yang tersebar dimana - mana

- Tidak ada biaya apabila transfer ke sesama Bank Mandiri cabang luar kota.

- Kemudahan dalam transaksi.

- Mempunyai sistem Mandiri Cash Management (MCM) yang memudahkan dalam transaksi seperti pengecekkan saldo, dll.

- Memberikan layanan prima kepada nasabah prioritas.

- Memudahkan nasabah dalam membayar operasional perusahaan seperti BPJS, Pajak, dll.

Sedangkan kekurangan dari Bank Mandiri yaitu sebagai berikut :

- Biaya besar untuk transaksi SKN \& RTGS

- Adanya hambatan dalam melakukan RTGS.

- Adanya kesulitan dalam melakukan transaksi, padahal nasabah prioritas

- Tidak semua pelayanan di kantor cabang memuaskan.

- Antrian yang panjang

- Log in sistem yang membutuhkan waktu yang agak lama.

Bank QnB Indonesia

Kelebihan Bank QnB Indonesia yaitu :
- Memberikan kemudahan akses pembayaran oleh penyewa.

- Tidak ada antrian yang panjang pada saat transaksi di teller.

- Terdaftar dalam ATM Bersama.

- Adanya program KTA.

- Pencairan dana pinjaman cepat Memberikan kemudahan informasi keuangan.

mandırı Sedangkan kekurangan Bank QnB Indonesia yaitu sebagai berikut :

- Hanya Terdapat satu kantor cabang di Batam.

- Sering terjadi gangguan pada saat melihat transaksi virtual account

- Log in sistem yang membutuhkan waktu yang agak lama.

\section{Fungsi Yang Terkait Dengan Penerimaan Kas}

○ Fungsi Koordinator Keuangan/Accounting Fungsi ini bertugas untuk membuat invoice atas tagihan berupa listrik, air, sewa ruang, sewa tanaman, sewa ruang pertemuan, dan lain-lain. Selain itu, koordinator keuangan juga membuat mutasi bank, mengontrol pembukuan kas dan membuat Laporan Posisi Keuangan (LPK).

- Fungsi Koordinator Piutang dan Sumber Daya Manusia (SDM)

Fungsi ini bertugas untuk menginput rekapitulasi piutang yang telah dibuat oleh koordinator keuangan dan melakukan penagihan atas piutang tersebut. Selain itu, fungsi ini juga bertugas sebagai Human Resources Department (HRD).

- Fungsi Kasir

Fungsi ini bertugas untuk membuat kwitansi atas penerimaan pembayaran secara tunai dan melalui bank. Selain itu, fungsi ini juga membuat pembukuan mutasi kas dan melakukan pembayaran biaya operasional perusahaan.

- Fungsi Kepala Departemen Keuangan Fungsi ini bertugas untuk memeriksa pembukuan mutasi kas dan bank serta membuat laporan fiskal. Selain itu, fungsi ini juga mempunyai peran un- 
tuk memberikan keputusan terhadap manajemen keuangan.

- Fungsi Manajer Keuangan

Fungsi ini bertugas untuk mengontrol dan memeriksa mutasi kas dan bank serta pengeluaran-pengeluaran operasional perusahaan. Selain itu, fungsi ini juga berperan penting terhadap pengambilan keputusan dalam manajemen keuangan.

\section{Dokumen Yang Digunakan}

- Faktur/Invoice

Faktur merupakan dokumen yang digunakan untuk menunjukkan perhitungan tagihan yang harus dibayar oleh penyewa. Pada perusahaan ini, faktur yang dibuat berupa faktur listrik, faktur air, faktur sewa ruang pertemuan, faktur sewa shaft, faktur sewa banner, dan lain-lain.

- Kwitansi

Kwitansi adalah dokumen yang digunakan sebagai bukti pembayaran yang dilakukan oleh penyewa atas tagihan yang menjadi beban untuk mereka.

- Bukti Kas Masuk

Bukti kas masuk merupakan dokumen yang digunakan sebagai bukti bahwa perusahaan telah menerima uang secara tunai dari penyewa dengan melampirkan dokumen pendukung seperti kwitansi dan faktur.

- Mutasi Bank Masuk

Bukti bank masuk adalah dokumen yang digunakan sebagai bukti bahwa perusahaan telah menerima uang yang ditransfer oleh penyewa ke rekening perusahaan dengan melampirkan bukti pendukungnya yaitu kwitansi dan faktur.

- Mutasi Kas / Bank

Mutasi kas/bank merupakan dokumen yang menggambarkan arus masuk dan keluar kas. Sehingga di dalam mutasi kas/bank tersebut menunjukkan posisi atau saldo kas yang ada, baik uang kas secara fisik (tunai) ataupun uang yang ada di rekening perusahaan.

\section{Catatan Akuntansi Yang Digunakan}

Di dalam sistem penerimaan kas pada PT Batam Jaya Propertindo, menggunakan catatan akuntansi yang digunakan yaitu jurnal penerimaan kas baik tunai maupun yang ditransfer melalui bank sesuai dengan jumlah yang diterima dari penyewa. Selain itu, diperlukan jurnal koreksi untuk menunjukkan pencatatan pada posisi sebenarnya.

\section{Pencatatan Penerimaan Kas}

Uang yang diterima dari penyewa baik itu melalui tunai atau transfer pada rekening perusahaan, harus dibuat bukti penerimaan kas yang berupa kwitansi. Namun, pada saat membuat kwitansi, harus memperhatikan jumlah tagihan yang ada difaktur dan jumlah yang dibayarkan oleh penyewa. Karena, terkadang ada penyewa yang melunasi tagihannya berbeda dengan jumlah yang ada difaktur. Hal ini disebabkan oleh adanya pajak yang dikenakan kepada penyewa. Jika penyewa melunasi tagihan berdasarkan jumlah yang ada di dalam faktur, maka pajak atas sewa yang dikenakan dibayarkan oleh perusahaan. Apabila penyewa melunasi tagihan tidak sesuai dengan jumlah yang ada di dalam faktur, maka penyewa itu sendiri yang membayar pajak dan harus memberikan bukti potong pajak kepada perusahaan. Dengan demikian, jumlah yang dicatat pada kwitansi, bukti kas/bank masuk, dan mutasi kas harus sesuai dengan jumlah uang yang diterima. Sehingga, tidak akan ada kesalahan pencatatan maupun jurnal koreksi yang diperlukan.

\section{Pajak Yang Dikenakan Kepada Penyewa}

Pajak merupakan hal yang wajib dibayarkan oleh individu maupun perusahaan. Sehingga, perusahaan properti seperti PT Batam Jaya Propertindo dikenakan pajak penghasilan (Pph) pasal 4 ayat 2 dan pajak penghasilan (Pph) pasal 23 yang nantinya menjadi beban penyewa. Pajak penghasilan (Pph) pasal 4 ayat 2 dikenakan atas sewa ruang, sewa executive of- 
fice, sewa virtual office, listrik, sewa rooftop, sewa shaft, dan sewa ruang pertemuan. Sedangkan untuk pajak penghasilan (Pph) pasal 23 dikenakan atas sewa tanaman, jasa kebersihan ruangan, renovasi ruangan, servis $\mathrm{AC}$, dan lainlain.

\section{Waktu Pembuatan Faktur/Invoice dan Kwit- ansi}

Pada PT Batam Jaya Propertindo, faktur dibuat oleh koordinator keuangan yang dibuat pada waktu-waktu tertentu. Adapun waktu-waktu tersebut antara lain :

1. Pada saat ada penyewa baru. Pada saat ini, staff marketing memberikan form aplikasi sewa dan meminta untuk dibuatkan faktur berdasarkan form aplikasi tersebut. Hal ini biasanya dilakukan untuk sewa ruang pertemuan.

2. Pada saat jatuh tempo kontrak. Pada saat ini, koordinator keuangan memeriksa daftar penyewa yang akan habis kontrak. Kemudian, staff tersebut melakukan konfirmasi kepada staff marketing mengenai status kontrak. Apakah disambung atau tidak oleh penyewa. Jika penyewa menyambung kontrak, maka staff langsung membuat faktur sewa. Biasanya ini dilakukan sebulan sebelum kontrak habis dan dikenakan untuk sewa ruang, sewa shaft, dan sewa executive office.

3. Pada saat akhir bulan. Pada saat ini, staff membuat faktur untuk listrik sesuai dengan pencatatan yang diberikan oleh staff teknik berdasarkan besarnya Kwh yang dimiliki oleh penyewa.

Sementara itu, pembuatan kwitansi dilakukan pada saat ada penyewa baru dan penyewa lama yang melakukan pembayaran secara tunai maupun melalui transfer ke rekening perusahaan.

\section{Prosedur Penerimaan Kas}

- Penyewa datang ke kantor dan bertemu
Denganstafmarketinguntuk menanyakan sewa ruangan dan melakukan tandatangan Kontrak atau Berita Acara Kesepakatan (BAK) apabila sudah ada kesepakatan antara kedua belah pihak. Kontrak atau BAK dibuat dua rangkap yaitu untuk penyewa dan untuk arsip marketing.

- Setelah menandatangi kontrak atau BAK, marketing memberikan fotocopy dokumen tersebut kepada staf koordinator keuangan untuk dibuat faktur apabila dibayar secara kredit. Apabila dibayar langsung atau secara tunai maka tidak perlu dibuat faktur.

- Apabila dibayar secara tunai, maka kontrak atau BAK satu rangkap diberikan kepada penyewa beserta kwitansi yang dibuat oleh kasir.

- Kemudian, Staf koordinator keuangan membuat faktur tiga rangkap. Lembar pertama untuk penyewa dan lembar kedua untuk staf koordinator piutang dan sumber daya manusia serta lembar ketiga sebagai arsip.

- Lalu, staff koordinator piutang menginput faktur lembar kedua. Apabila ada penyewa yang melunasi faktur, maka staff ini memberikan faktur tersebut kepada kasir agar dibuat kwitansi dan sebagai lampiran kasir untuk bukti kas masuk.

- Kemudian, kasir membuat kwitansi yang terdiri dari dua rangkap. Lembar pertama untuk penyewa dan lembar kedua sebagai lampiran kasir untuk bukti kas masuk.

- Kemudian, kasir membuat bukti kas masuk dengan lampiran kwitansi dan faktur lembar kedua dan menginput bukti kas masuk tersebut pada mutasi kas.

- Apabila ada penyewa yang melakukan pembayaran melalui bank, maka staff koordinator piutang mengecek rekening koran dan meminta kasir untuk membuat kwitansi. Kwitansi lembar pertama untuk penyewa dan kwitansi lembar kedua sebagai lampiran untuk bukti bank masuk. 
- Lalu, staff koodinator keuangan membuat bukti bank masuk dan menginputnya pada mutasi bank.

- Setelah itu, bukti kas masuk dan bukti bank masuk yang telah dibuat, diserahkan kepada kepala bagian keuangan untuk diperiksa.

- Kemudian, bukti kas masuk dan bukti bank masuk yang sudah diperiksa oleh kepala bagian keuangan, diserahkan kepada manajer keuangan untuk diperiksa kembali.

- Pada setiap akhir bulan, mutasi kas dan mutasi bank diperiksa oleh kepala bagian keuangan dan manajer keuangan. Untuk lebih jelasnya, dapat dilihat pada flowchart sebagai berikut :

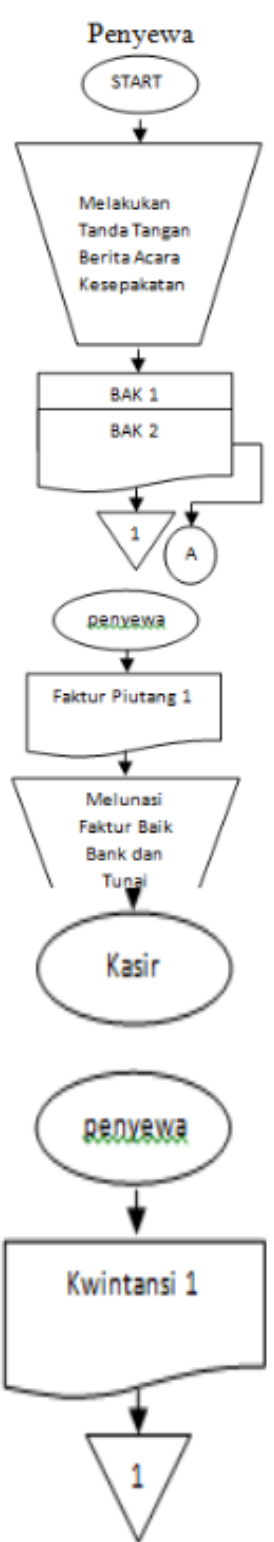

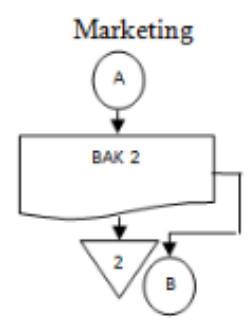



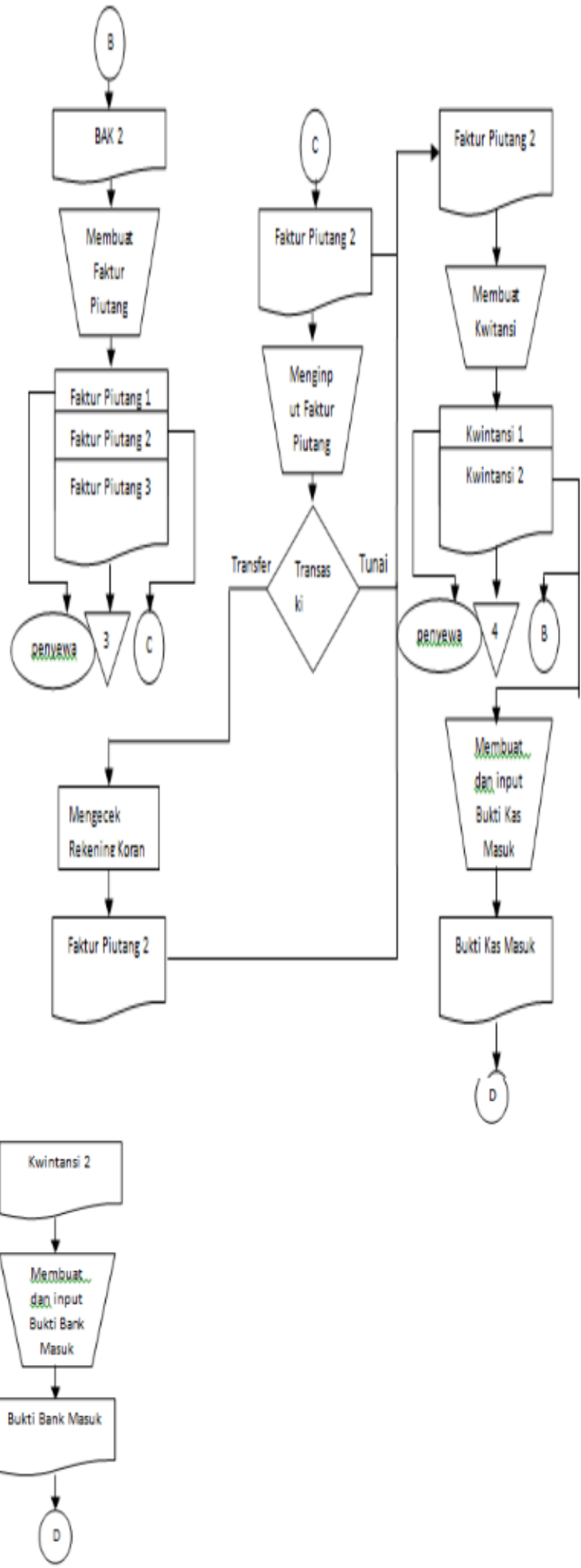
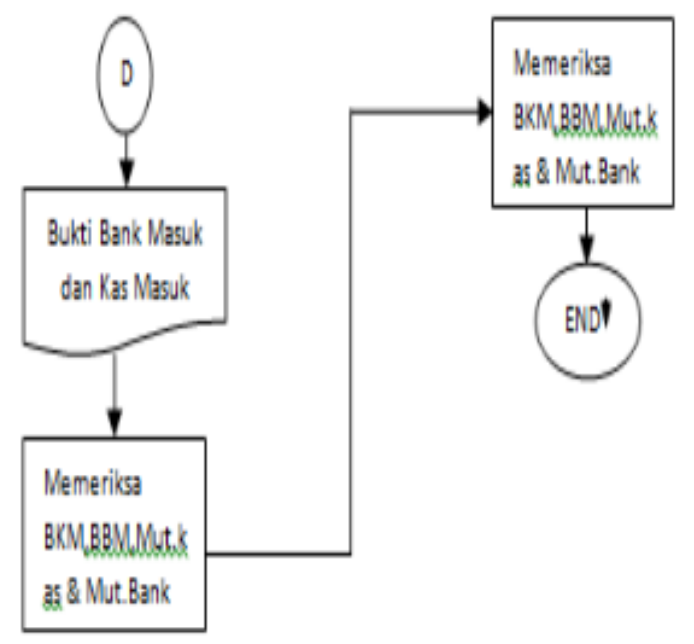

SistemPengendalian Penerimaan Kas

1. Struktur organisasi yang memisahkan tanggung jawab fungsional secara tegas. Pada perusahaan ini, terdapat pemisahan tanggung jawab di dalam departemen administrasi umum dan keuangan. Setiap staff harus bertanggung jawab terhadap pekerjaan yang telah ditetapkan oleh pihak manajemen perusahaan.

2. Sistem wewenang dan prosedur pencatatan yang memberikan perlindungan yang cukup terhadap kekayaan, utang, pendapatan dan biaya. Di dalam perusahaan, setiap transaksi yang terjadi berdasarkan persetujuan pejabat yang berwenang. Sehingga, hal ini akan menghindarkan dari penyalahgunaan atas tanggung jawab yang dilakukan oleh orang lain.

3. Praktik yang sehat. Pada perusahaan ini, Setiapstaffkhususnyadepartemen administrasi umum dan keuangan melakukan semua aktifitas pekerjaannya secara detail. Para staff melakukan tugasnya dengan rapi dan sesuai prosedur yang telah ditetapkan. Adapun tugas yang dilakukan antara lain :

- Bagian koordinator piutang membuat rekapitulasi piutang dan menagih piutang kepada penyewa. 
- Bagian koordinator keuangan membuat Dan menginput faktur dengan memberikan nomor faktur. Selain itu, staff ini juga mengontrol bukti bank masuk dengan memberikan nomor bukti bank masuk pada saat menginputnya pada mutasi kas.

- Bagian kasir membuat rekapitulasi nomor kwitansi dan memberikan nomor pada bukti kas masuk. Sehingga dokumen yang telah digunakan dapat terkontrol dengan baik.

4. Karyawan yang mutunya sesuai dengan tanggung jawabnya. Pada perusahaan ini, semua karyawan mempunyai tugas lebih dari satu. Artinya, setiap staff tidak hanya fokus pada satu tugas saja. Tetapi, setiap staff mempunyai tugas yang merangkap. Seperti, staff koordinator piutang yang merangkap sebagai HRD (Human Resources Department)I, staff koordinator keuangan yang merangkap sebagai kasir (jika dibutuhkan) dan controller terhadap omset perusahaan, kasir yang merangkap sebagai staff administrasi dan controller piutang telepon, kepala bagian keuangan yang merangkap sebagai controller pajak dan laporan keuangan, staff driver yang merangkap sebagai purchasing, dan manajer keuangan yang bertugas untuk memberikan keputusan dan mengontrol terhadap arus kas serta kinerja karyawan.

\section{KESIMPULAN DAN SARAN \\ Kesimpulan}

Sesuai analisis dan pembahasan yangtelah dilakukan oleh penulis, maka dapat disimpulkan hasil penelitian adalah sebagai berikut :

1. Dalam memilih suatu bank, perusahaan pasti akan melihat kualitas fitur dan layanan yang dimiliki oleh bank tersebut. Salah satunya yaitu e-banking. Dengan adanya e-banking terutama virtual account, maka hal ini akan memberikan kemudahan bagi pihak perusahaan untuk mengetahui dan melakukan pencatatan terhadap uang yang masuk pada rekening perusahaan. selain itu, pihak perusahaan juga tidak perlu pergi ke bank ter- sebut, karena transaksinya dapat dicek langsung pada website yang telah disediakan oleh pihak bank. Sehingga, penggunaan terhadap waktu dan biaya lebih efisien dan efektif.

2. Sistem pengendalian intern penerimaan kas pada PT Batam Jaya Propertindo telah berjalan efektif. Hal ini dapat dilihat dari unsur-unsur pengendalian intern pada perusahaan tersebut. Meskipun para staff mendapatkan pekerjaan yang merangkap, tetapi hal ini tidak menjadi penghalang bagi staff untuk bekerja dengan jujur dan kompeten dalam melaksanakan tugas

mereka masing-masing. Selain itu,perusahaan juga mendapatkan pertanggungjawaban keuangan yang dapat diandalkan dan dipercaya. Kemudian, ketatnya pengawasan terhadap kas yang dilakukan dapat menjadi benteng terhadap resiko penyelewengan kas perusahaan.

\section{Saran}

Setelah melakukan penelitian mengenai kualitas $e$-banking dan sistem pengendalian intern penerimaan kas pada PT Batam Jaya Propertindo, maka saran yang dapat penulis kemukakan antara lain sebagai berikut :

1. Untuk setiap penyewa baru dan penyewa lama, dibuatkan nomor virtual account sehingga pada saat penyewa tersebut melakukan pembayaran dapat langsung diketahui oleh staff keuangan. Sehingga tidak akan membuang-buang waktu untuk menunggu konfirmasi dari penyewa. Dengan demikian, pekerjaan dapat berjalan dengan efektif dan efektif.

2. Diperlukan pengawasan yang lebih ketat lagi dari yang sebelumnya dan pihak manajemen harus membuat sanksi yang tegas bagi siapa saja yang berusaha untuk melakukan penyelewengan terhadap kas agar hal tersebut tidak terjadi. 


\section{DAFTAR PUSTAKA}

Amin, H. "Internet Banking Adoption among Young Intellectuals". Journal of Internet Banking and Commerce, 2007.Vol. 12, No.3

Bodnar, George H dan William S. Hopwood. (2006). Sistem Informasi Akuntansi. Yogyakarta: ANDI

Davis, F.D., "Perceived Usefulness, Perceived Ease of Use and User Acceptance of Information Technology". MS Quartely. 1989. Vol.13 Iss.3, pg.318 diakses dari.http://www.cba.hawaii.edu/chrismar /IT M704/DavisTAM1989.pdf., pada 24 Januari 2016

Ely Suhayati., \& Siti Kurnia Rahayu. (2010). AUDITING, Konsep Dasar dan Pedoman Pemriksaan Akuntan Publik. Yogyakarta : Graha Ilmu.

Federal Financial Information Examination Council. E-Banking. IT Examination Handbook. FFIEC, USA, 2003.

Hamta,SE,M.Si, Firdaus. (2015). Metode Penelitian Akuntansi. Yogyakarta: Deepublish

Hall, James A. (2007). Sistem Informasi

Akuntansi. Jakarta: Salemba Empat

------------(2011). Sistem Informasi

Akuntansi. Jakarta: Salemba Empat

Harahap. 2011. Laporan Arus Kas. Salem-

ba Empat, Jakarta.

Standar Akuntansi Keuangan. (2012). Revisi 1 Juni 2012. Jakarta: Ikatan Akuntan Indonesia

Kasmir. 2008. Bank dan Lembaga Keuangan

Lainnya. Edisi Revisi 2008. Jakarta: PT Raja Grafindo Persada

Mandiri Bank. Corporate Info. Profil Perusahaan, Dalam

http://www.bankmandiri.co.id/contact.as px, 14 Maret 2016.

Mulyadi. (2001). Sistem Informasi Akuntansi.

Jakarta: Salemba Empat

QnB Bank. QnB Indonesia history. Dalam http://www.qnb.co.id/lang/en/about/, 14 Maret 2016.

Rahmi, Dhinie. 2013. Penggelapan Uang di Greater Providence Deposit And Trust. (http://dhinierahmy.blogspot.co.id/2013/ 01/tugas-sia.html), diakses 24 Januari 2016)

Sakharosa, Citra Dewi Fortuna. 2013. Pengaruh Faktor Individu, Organisasi dan Sistem terhadap Sistem Penerimaan E-Banking. Jurnal Ekonomi. (Online), (http://jimfeb.ub.ac.id), diakses 24 Januari 2016) Shofiana, Nur. 2011. Analisis Faktor-faktor yang Mempengaruhi Tingkat Kepercayaan Nasabah Pengguna Internet Banking (Studi Kasus di Bank Syariah Mandiri Cabang Semarang. Jurnal Ekonomi. (Online), (http://library.walisongo.ac.id/digilib/file s/disk1/114/jtptiain-gdl-nurshofian5667-1-062411057.pdf), diakses 24 Januari 2016)

Silvia, Maya Angela. 2014. Faktor-faktor yang Mempengaruhi Minat Nasabah Menggunakan Internet Banking pada PT. Bank Rakyat Indonesia (PERSERO) Tbk, Cabang Ahmad Yani Makassar. Jurnal Ekonomi. (Online), (http://repository.unhas.ac.id/bitstream/h andle/123456789/14128/SKRIPSI\%20L ENGKAP\%20MAYA.pdf?sequence $=1$ ), diakses 24 Januari 2016

Virtual Account Bank BNI, Dalam http://bni.co.id/id.id/bankingservice/businessban king/service/cashmanagement/collection management/virtualaccount.aspx 14 Maret 2016.

Yuliana. 2006. Analisis Pengendalian Intern Kas Pada PT Bank Negara Indonesia Cabang Pembantu Binjai. Jurnal Ekonomi. (Online), (http://repository.usu.ac.id), diakses 24 Januari 2016). 